\title{
EchoGéo
}

31 | 2015

Glocal Ethiopia

\section{Glocal Ethiopia: Scales and Power Shifts}

Introduction

\section{Sabine Planel et Marie Bridonneau}

\section{CpenEdition}

Journals

Édition électronique

URL : https://journals.openedition.org/echogeo/14219

DOI : $10.4000 /$ echogeo.14219

ISSN : 1963-1197

Éditeur

Pôle de recherche pour l'organisation et la diffusion de l'information géographique (CNRS UMR 8586)

Référence électronique

Sabine Planel et Marie Bridonneau, "Glocal Ethiopia: Scales and Power Shifts », EchoGéo [En ligne], 31 | 2015, mis en ligne le 10 avril 2015, consulté le 31 juillet 2021. URL : http://

journals.openedition.org/echogeo/14219; DOI : https://doi.org/10.4000/echogeo.14219

Ce document a été généré automatiquement le 31 juillet 2021.

EchoGéo est mis à disposition selon les termes de la licence Creative Commons Attribution - Pas d'Utilisation Commerciale - Pas de Modification 4.0 International (CC BY-NC-ND) 


\section{Glocal Ethiopia: Scales and Power Shifts}

Introduction

Sabine Planel et Marie Bridonneau

With special thanks to René Lefort for his attentive reading and precious comments, which we integrated into this text.

1 Never quite isolated from the world but nonetheless always keen to control its international relations, Ethiopia is a recent convert to extraversion: the country has engaged into in-depth political, economic and social reform. The lower scales are transforming under the pressure of the global. To respond to the federal government's commands, infra-national scales are attempting to seize long-awaited development opportunities. Ethiopia is becoming glocal: the local is coming into direct contact with the global, sometimes under the incentive of the federal State.

2 As is the case everywhere else, but even more so within Ethiopia's complex ethnofederal structure (Turton, 2006; Vaughan, 2003), scale relations reflect power relations. The powers of globalization are recent and have the potential to deeply reshape politics by outweighing the national scale. With this special issue, we aim to document and analyse scale relations in order to understand their consequences on the transformation of Ethiopian societies, on national economic growth and on the evolution of political practices. The articles focus on local analyses, drawing from a detailed understanding of the interaction between local stakeholders and looking at global integration from a bottom-up perspective. Our objective is twofold: first of all, to describe the emergence of a new Ethiopia, transformed by the restructuring of its interaction with the world, which mostly occurs on a local scale. Secondly, to capture the qualitative aspects of these shifts in scale and of the redistribution of powers over space, as those changes are having a deep and lasting impact on the country's future, regardless of its relations with the rest of the world. In other words, our purpose is not to draw a detailed picture of all the socio-spatial transformations currently affecting contemporary Ethiopia, but to deliver a scale-based reading of these transformations in order to understand them more comprehensively. 
Our analysis has multiple objectives. First and foremost, this special issue analyses power along with spatial transformation, in order to understand politics in all its materiality and historicity. It also questions the role played by the State, which is currently at the core of all discussions on Ethiopian development. This question is connected to the major ideological transition currently in progress in Ethiopia, where territorial and social equalitarianism are being replaced by more differentiated policies. Finally, this issue is an invitation to read Ethiopia's reality through the prism of a very common process of scale structuration (i.e. globalization) in an attempt to move away from the paradigm of cultural exception, often predominant in Ethiopian studies (Tronvoll, Vaughan, 2003).

\section{The market economy and its benefits}

4 From 1991, the new regime announced political and economical liberalisation (Hagmann, Abbink, 2011; Lefort, 2012; De Waal, 2013). However in spite of a gradual, sector-by-sector reorientation of public interventionism, this process was delayed, as illustrated by the abandonment and reinstatement of price control policies (Vaughan, Gebremichael, 2011). It was only from the early 00s that the effects of the regime change began to be felt. This change was caused by several factors. First of all, liberalisation was the product of a truly original and innovative political vision championed by former Prime Minister Meles Zenawi, "a truly original thinker" (De Waal, 2013), aimed at answering the needs of the market economy. It was brought about by the new ratio of power within the Ethiopian government's political leadership (Lefort, 2013) and by the failure of previous development policies, which became apparent with the huge food crisis of 2000/02 or with the electoral defeat of the ruling party in 2005. Whatever the reason, this highly publicised «structural change " (Gascon, 2008; Bach, 2011) orchestrated by Meles Zenawi (2012) acted as a crucial lever for the regime and contributed to its remaining in power.

Ethiopia's engagement with the market economy only became tangible from the end of the 00s. Until then, the country's development model had been both autocentric and endogenic. Its opening to the market economy was then relatively fast, and accelerated after the 2005 electoral defeat. It became associated with the politicians' - and in particular, the Communist party's - ambition to regain control of the country. This led to the 2009 government reform or Business Process Reengineering (Kassahun, 2012), and to the 2010 launch of a new plan for development, the Growth and Transformation Plan (2010/2011 - 2014/2015). The plan implied for the State to take the lead and deliver on the construction of large-scale infrastructure ${ }^{1}$ but also on education and healthcare, in order to foster growth and reduce poverty (FDRE, 2010). While asserting the key leadership role played by the State in terms of economic growth, the plan also promoted an engagement with the market which had been inexistent in the country's past development policies (also known as pro-poor policies), which focused on poverty, food safety and social welfare ${ }^{2}$ (Dessalegn Rahmato et al., 2013). Food self-sufficiency was at the time seen from an individual perspective and understood as a product of each farmer's own capacity: it became a national issue that relied upon the capacities of the best food producers, or model farmers (Lefort, 2012). The Growth and Transformation Plan had two key objectives: to foster sustainable growth across all of the country's economic sectors, bringing Ethiopia up to the level of other emerging countries by 
2025, and to ensure the transition from an economy based on small-scale farming ${ }^{3}$ towards industry and service-led growth (Meheret Ayenew, 2014).

Gradually, good governance, anti-corruption measures and the fight against "rent sekers", together with metropolisation and urban redevelopment, are working their way into Ethiopia's economy, revolutionising a developmental grammar directly derived from Marxist-leninist theories (FDRE, 2010; Meles Zenawi, 2012). This renewal didn't amount to a "shock therapy": on the contrary it was sequenced, regionalised and sectorised. Liberalisation mostly translated into a reorganisation of public policies. The State carried on playing an essential part in planning and in the structuring of the economic fabric which remained for the most part structured around public or parapublic organizations (Vaughan, Gebremichael, 2011), and it continued playing a key part in funding the country's economy. Ethiopia has the third highest ratio in the world of public investment to GDP, because there is very limited private investment in the country. Along with liberalisation came the creation of a modern banking system designed to stimulate private investment, in particular by facilitating borrowing. It has to be noted that in spite of the rapid growth of private banks, State commercial banks remain predominant (Admassu Bezabeh et Asayehgn Desta, 2014). Micro-credit has also become institutional - once again under the public sector's umbrella - via regional structures such as the ACSI (Amhara Credit and Saving Institution) that reported over 1.4 million clients in the State-region of Amhara in 2009 (Siyoum et al., 2012).

7 This economic reform requires Ethiopia to fully enter the global economy and attract foreign investors, while retaining the support of donors (World Bank, 2013). Foreign investment had so far been strictly controlled and restricted to specific sectors such as horticulture, but globalisation has made it commonplace - with for instance the exnihilo creation of the country's sugar industry. The Ethiopians of the diaspora benefit from favourable investment conditions (Chacko, Gebre, 2012); calls for public tenders are increasingly directed at foreign providers (mostly Chinese and Indian, in the agricultural sector). Ethiopia's connections with the world have improved, with Addis Abeba becoming a regional airline hub. This ambition also appears in the transformation of city centres: business districts are shooting up in the capital, revealing its aspirations to metropolitan status, its role as a showcase for the commercial sector and the new role it is offering to private investors (Bosredon et al., 2012; Pedrazzini et al., 2014).

8 This economic reorientation is starting to bear its fruits. In 2011/12, per capita income was reported to be in the region of 513USD and to have significantly increased since the launch of the GTP. According to the government, growth increased by over $10 \%$ per year in the first two years that followed the implementation of the GTP. These figures were quoted by international donors (World Bank, 2013) who have since revised them down to around 6\%. In 2010, Meles Zenawi publicly announced a growth rate of $12.5 \%$. The various indicators produced by national agencies reflect an impressive growth. The percentage of people living under the poverty line is reported to have gone down from $38.7 \%$ in $2003 / 04$ to $29,6 \%$ in 2010/11, while gross national savings as a percent of GDP are reported to have reduced from $5.2 \%$ in $2009 / 10$ to $1.8 \%$ in just a year! Meheret Ayenet does however discuss the part played by the GDP in this economic improvement, and points at the weaknesses of the Ethiopian economy: amongst other issues, problems with balance of payments deficits due to the structural weakness of exports, although there has been a clear improvement on this front ${ }^{4}$; a deficit in tax 
collection and a high inflation rate $(34,3 \%$ in $2011 / 12)$ preventing most Ethiopians from reaping the benefits of growth.

Similarly, no clear effects have been felt in terms of employment, and the transition from agricultural labour to urban employment is for now restricted to small sectors of activity, in particular flower farms (Yukichi Mano et al., 2011) or even more marginally, tourist areas (Bridonneau, 2014a). The employability of young people in general and young graduates in particular remains an issue (Broussard et al., 2014). 2 to 2.5 million young Ethiopians arrive on the job market every year and are unable to find any employment perspectives, neither in saturated family farming nor in underdeveloped industrial and service sectors. UNDP estimates urban unemployment at $17.5 \%$ of the population while agriculture remains the main activity for $80 \%$ of Ethiopia's population (UNDP, 2014). Youth unemployment and its correlation with the perpetuation of rural and urban poverty contribute to the development of migration, especially female, to Gulf countries. Cheap Ethiopian labour is in demand there while on the Ethiopian side, income from migrants provides a sizeable and essential contribution to economic growth (Fernandez, 2011)

10 Finally, the real or symbolic effects of this economic transformation trigger and reinforce social transformations. New categories of population are appearing, bringing new distinctions into the equalitarian society the country had inherited from the Derg. Urban middle-classes (Nallet, 2012), new entrepreneurs in cities and rural areas, foreign-trained experts (Bridonneau, 2014a), Pentecostal evangelists (Haustein and Fantini, 2013) or young urbans (Di Nunzio, 2015) are all shaping up a new Ethiopian society and contributing to its opening up to the world.

11 However, this reorientation relies on an ambitious challenge: while structuring itself, the private sector needs to be in a position to take over from public investment (World Bank, 2013). This challenge currently seems compromised by two main factors. The public sector's strong influence on the one hand, and the Ethiopian State's lack of resources on the other hand hardly make for an attractive environment. Access to licences, the weight of bureaucratic red tape and the recent tax reforms are slowing down the development of the private sector and the penetration of foreign investors. Similarly, the self-funding of national development - through public investment or recourse to "voluntary contributions" from the Ethiopians and civil servants in particular - appears compromised by public deficit.

12 The transformation of the economic model does cause numerous tensions, which appear in particular in land management. In Ethiopia, power and land ownership have always been closely linked (Dessalegn Rahmato, 2009; Emmenegger, 2013). Today more than ever, access to property reflects the public sector's contradictions - between a need for private sector intervention and the public sector's unwavering tendency to keep its grasp on financial resources. Land management reflects the Ethiopian State's ability to promote an endogenous model geared towards the highest possible degree of self-financing. Land titling reforms and land grabbing policies are indeed the products of a national strategy, rather than markers of a development agenda dictated by international donors (Lavers, 2012). This new agricultural policy, promoted and managed by the government, detracts attention from the development of small-scale agriculture (Dessalegn Rahmato, 2011; Lefort, 2011). However, as was the case elsewhere in Sub-Saharan Africa, land grab turned out to be a failure as only a very small amount of land was eventually handed over to foreign investors (a few tens of 
thousands acres so far instead of the planned 3 to 4 millions) (Dessalegn Rahmato, 2014). In urban spaces, and now in peri-urban spaces, public leases provide a widespread economic reorientation tool. Although the totality of the land, whether urban or rural, remains State property (and has been since the Derg-led reforms of 1975), a series of laws on urban leases have created a State-controlled land market (Berhanu Adenew, Fayera Abdi, 2005). In peri-urban spaces, the transition from rural to urban usage and the attribution of land through the leasing system led to the expropriation of rural populations, essentially for the benefit of urban public housing programs and property developers who are urbanising sprawling urban margins (Achamyeleh Gashu Adam, 2014).

Ethiopia's strong economic growth hides structural weaknesses. The lack of private investment is concealed behind significant levels of public investment that drain the State's resources, making the country more dependent than ever on international aid and diaspora money. Two thirds of the economy, outside of traditional agriculture, are State-controlled. The political elite's permanent control over the economy is an obstacle to the economy's liberalisation, repelling the very same private investments that the regime is paradoxically so keen to attract (Lefort, 2013). Save for a few exceptions, the economic elite is the same as the State Party's elite. In general, except perhaps for its partnership with China, Ethiopia's engagement with international markets is currently characterized by a great unbalance -both financial and institutional.

\section{A Non-Democratic Developmental State}

14 The country's economic reorientation follows a hybrid development model borrowed from South-East Asian countries, which has been adapted to Ethiopia's situation. This model of the "Developmental State" associates the benefits of the market economy with strong public sector control (Bayart, 2008; Meheret Ayenew, 2014). It implies that the development of a market economy, which is seen as a priority, can bring about political liberalisation (Assefa Fiseha, 2014). Like other more typically liberal models, it is based upon the link between economic growth and democratisation: a link highlighted by Meles Zenawi when he defined the "Democratic Developmental State". Zenawi sees democracy as the masses' contribution to development, which makes him the heir of the Revolutionary Democracy of the past (Bach, 2011). However, the model he is promoting is much more attractive to donors. Although the effectiveness of political liberalisation is widely debated in academic circles, it is much less so in Ethiopia's public arena where political opposition parties are almost inexistent and censorship has been reinforced. In terms of political democratisation, Ethiopia's case is highly ambiguous. What we are witnessing is more akin to a consolidation of constraints than to a development of democratic practices (Abbink, Hagmann, 2013). This observation is based on a detailed analysis of local situations rather than on that of government models (although the latter do also reflect the regime's authoritarianism): the near absence of any political opponents at Parliament, the uninterrupted rule for almost twenty years of a quasi-unique party, the EPRDF (Ethiopian People's Revolutionary Democratic Front), the personalization of power in the person of the former Prime Minister, etc.: 
«In the Ethiopian case, the State has narrowed the space for the engagement of civil society, opposition parties and, to some extent, the private sector, and hence one may say the autonomy of the state is preserved - albeit under an authoritarian political order » (Meheret Ayenew, 2014, p. 8).

Signs of political openness displayed for the attention of the international community and Ethiopian civil society including - and particularly - diaspora-led organizations, are increasingly frequent but they remain tokenistic. This is reflected by the case of regional decentralisation. Initiated in 1991 with the creation of nine regional states, it was implemented over several stages and resulted in an overhaul of local administrations and governments, from the wereda through to the kebele ${ }^{5}$. The latter were consolidated by the introduction of more qualified management staff, and their remit was extended to cover new sub-districts (the sub-kebele). Local government is now particularly mixed, with many institutions stemming from the civil society. The reform has consolidated a very strict and highly politicized system of social control, enforced through various interlocked committees and cells, the most hybridated of which are the "development groups" (Lefort, 2010). Similarly, because decentralisation has followed an ethno-federal model where new administrative structures were based upon ethno-linguistic delineations, this policy was made harder to implement by the fact that territorialisation, and in particular the delineation of each administration's remit, were highly controversial issues (Asnake Kefale, 2010). Indeed, ethnic belonging is constantly being re-appropriated, rewritten and reallocated, in the North and particularly in the South of the country (Aalen, 2011; Osmond, 2014). Consequently, although decentralisation, and in particular the consolidation of local administrations, granted the populations better access to public services (Emmenegger et al., 2011) ${ }^{6}$, it also contributed to curbing political liberalisation (Teferi Abate Adem, 2004) - because it created a higher level of de-concentration in public administrations (for instance when the nomination of a devolved manager, the kebele manager, brings about increased standardisation and supervision of local government) but more crucially because it reinforced State/Party collusion. In the former case, decentralisation is seen as a conservative force (Planel, 2007), while in the second it is seen as deceptive (Bjerkli, 2013).

16 As is the case in other African countries, decentralisation is designed to foster a new style of public management: in Ethiopia this translates into the promotion of participatory policies, and in the civil society becoming more structured. Since the mid-90s, participatory policies have created a new relationship between the State and their beneficiaries: a relationship of an increasingly contractual, individual and financial nature, but one that nonetheless remains more or less authoritarian (Planel, 2014). The creation of new institutions, in particular local ones, combined with good practice-inspired measures aimed at structuring the civil society, are intended to contribute to a renewal of local politics (Poluah, 2008). However, this ambition to structure the civil society clashes with more typically Ethiopian control methods.

From a pragmatic point of view, these measures have had diverse consequences although governance practices do not really reflect the intended institutional renewal. Some authors observed a genuine adaptation of local communities to the new commands (Lefort, 2012), or even an appropriation of these commands that can lead to the capture of power (Emmenegger et al., 2011; Segers, 2008; Pausewang, 2002b). Others on the contrary report the persistence, and even the consolidation, of authoritarian practices, perpetuating ruling practices or cultural representations that revolve around 
relations of domination (Abbink, 2011), especially in the relation between the State and the farming community (Dessalegn Rahmato, 2009; Lefort, 2010; Aspen, 2002, Pausewang, 2002a). State supervision of local spaces is so intense that it increases control rather than fostering development, because of the high political stakes attached to development (Planel, 2014).

This phenomenon is mostly due to the confusion between the State and the Party, which remains the main cause of political grabbing. The ruling party has created a highly centralized system, with a solid footing in the urban and rural middle classes. It is taking longer than expected to implement the mutations that started in the early 2000s (when the political ratio of power changed in the ruling cabinet), and its legitimacy was widely challenged at the general election of 2005, whose outcomes were fiercely disputed (Lefort, 2010; Bach, 2012). However, the Party remains powerful and has now undertaken to regain control over its electorate. The Party is trying to recruit more members in order to remain as close as possible to the people: its membership went from 760,000 in 2005 to 4 million in 2010 (Vaughan, 2011). The evaluation of public policies is increasingly based on measurable outcomes or "quotas" (Enten, 2010), and civil servants are subjected to diverse performance targets (Labzaé, to appear): this means that the State's achievements are used indistinctively to serve developmental objectives and to reinforce the Party. Similarly, collusions between the State and the Party are reinforced by the "Developmental State" model. The emergence of new economic players from the middle class echoes changes in the Party's membership, reflecting an intimate connection between political and economic strategies. The State has thus reinforced its links with the civil society and its diverse players (investors, young people, women, farmers and cooperatives) in order to encourage them to get involved in the development process.

19 The intense politicisation of the State's supervision structures, whether old or new and regardless of the electoral agenda - (Assefa Fiseha, 2014) has had multiple effects. The same corruption and rent-seeking strategies condemned by the government are still seen as opportunities for local officials to access the State's resources. Similarly, the expansion of the interface between the State apparel and local society has increased the number of political intermediaries, creating so many financial or political opportunities for the local population (Emmenegger et al, 2011). However, the ambivalence of the processes followed for the election/designation of local officials (Lefort, 2012; Assefa Fiseha, 2014) is making it very difficult for the population to access these posts. These various factors contribute to skewing public development policies and stopping them from reaching their objectives in a fair manner. Zenebe Uraguchi (2011) observes that the financial transfers made possible by safety net programmes in rural areas (Productive Safety Net Program, or Food-For-Work programs) are failing to support the development of farming in the medium term because the funds are mostly used to sustain the farmers through the lean season. Camilla Louise Bjerkli (2013) also observes that the regional decentralisation of Addis Abeba's waste management systems has created a multitude of institutions that serve party politics rather than urban development. Although these hierarchical structures do favour the reproduction of power, they can also provide young urbans with a space, however confined, for expression (Di Nunzio, 2014).

20 These measures are co-produced by hybrid administrations that are widely funded by foreign donors and development programmes: for this reason, they tend to reflect the 
neoliberal tendency to consider development as a purely technical process (Ferguson, 1994) - and precisely because of this apolitical preconception, they tend to reinforce authoritarian practices. This is aggravated by the fact that the collection of international aid by the various Ethiopian administrations creates complex power relations - which do not in any way alter the State's authoritarian government practices (Dereje Feyissa, 2011). Land registration or titling policies provide a particularly clear example of this distortion (Chinigo, 2014; Labzaé, 2014). They remain top-down policies, subjected to the same bureaucratic order and "democratic centralism" that presides over the design and implementation of public policies. This order reinforces the symbolic distance between the State and the citizens - a distance that becomes greater, the more the actual physical distance is shrinking - and imposes new or reinvented standards on the population. This contributes to perpetuating the domination of vulnerable populations (Planel, 2014).

21 The reform of the State has created strong tensions. The age-old correlation between economic dependency and political domination has reinforced authoritarianism. Reversely, the availability of new opportunities has allowed for a new elite to emerge. However, change remains partial at best and the general feeling is that voluntary servitude might one day turn into a win-win situation. Between the people's hope for change and the hardships of their everyday lives, between authoritarianism and the market economy, different players are taking advantage of the opportunities arising from the emergence of multiple scales of action.

\section{Ethiopian glocalisation?}

The notion of scale carries a rich palette of meaning, with the potential to generate diverse interpretations. Along with the supporters of the theory of scale ${ }^{7}$, we see it as a "social construct" (Brenner, 2001) that reflects the hierarchical organisation of social facts in space (Collinge, 1999; Herod, Wright, 2002). Scale can be seen as a dynamic structuring process that organises a given space into different levels of power (or scale structuration process) - rather than as an interlocking of different areas of influence. This conception can help us better grasp the subtlety of scale relations. Furthermore, analyses that factor in scale dynamics and structuration (Brenner, 2001, 2004; Swyngedouw, 1997) can help us gain a detailed understanding of the political and economic shifts that have arisen from globalisation and neoliberal transformations (Harvey, 2006; Jessop, 2002). The organisation of global exchanges, the rearrangement of national spaces and the economy's globalisation are reworking scale according to new models, such as glocalisation. The glocalisation phenomenon involves a double repositioning of space, looking at the two opposite "ends of the scale": the global and the local. It also implies an institutional restructuring from the national to the supranational and global scales on the one hand, and to the infra-national, regional, metropolitan or local scales on the other (Swyngedouw, 2004).

Considering space through the prism of scale dynamics can help reveal the power relations that underpin the production of space (Swyngedouw, 1997). As well as being perfectly adapted to today's political game, scale can also help us grasp the demultiplication and circulation of powers, and understand the materiality of politics (Elden, 2013). The de-centering and fragmentation of the State's powers are scale mechanisms that require us to investigate other types of powers, and in particular 
other institutions (Planel, Jaglin, 2014). Scale carries an obvious political dimension. Political rescaling has been frequently used as a tool by politicians or States, who promoted neoliberal change by favouring certain scales (local, regional or urban) to the detriment of single-scale national regulations (Brenner, 2004), or even by remapping electoral constituencies (Jonas, 1994). This political dimension is exemplified by the manipulation of scale for politico-administrative purposes, but it is also present in less institutional, more diffuse forms, whenever the control of space is perceived as a source of power. A given model of spatial organisation might come into competition with other sources of legitimacy but also with other territorial processes: this potential for conflict and political debate reflects that carried by scale organisation.

"This internal transformation of the public sphere - where initiative, decisionmaking and regulation powers are being handed over to the inferior spatial scales, and where complex combinations of interlocked and articulated scales are emerging (multi-level governance) - is a major force of spatial reorganisation in contemporary societies [...]. It is however important to stress that the specific type of re-calibration encountered in the public sphere, which has been thoroughly described, has not in any way evicted the others but has instead merged with them." (Planel, Jaglin, 2014, p. 38-39)

The coexistence, or hybridisation, of diverse dynamics in the political sphere is particularly acute in authoritarian contexts, where original forms of territoriality and political rationality prevail - or at least forms that present few similarities with Western democratic situations, where these shifts in the scales of power were initially designed. Furthermore, due to this coexistence in a political system such as the Ethiopian ethno-federation where a hierarchy between powers and standards has become part of the institutions, changes have mostly benefitted the economic sector.

Within the vast spectrum of scale shifts, why did we choose to look at glocalisation? Certainly because this process provides an original perspective on Ethiopia's current transformations. Indeed, the restructuring of scale does not spell the end of the national: on the contrary, it has reinforced the State's control over the Ethiopian space. The glocalisation phenomenon is therefore a consequence of globalisation. It involves a direct interaction between the global and the local, and an indirect relation with the intermediary echelons - the regional level and particularly, in the case of Ethiopia, the national level. This encounter between the two opposite ends of the scale does not appear, as far as we know, to have an influence on the global echelon. It has however contributed to an in-depth transformation of local spaces, and has turned the local alternatively into the grounds of a genuine political negotiation or a simple management echelon.

The interface between the lower echelons of the State and local societies has recently gained more importance: this is the result of the Party's ambition to reinforce its local foothold, but also a product of glocalisation. New institutions, new players and new values are emerging in local spaces and revealing - within the boundaries of the State's tolerance - new political arenas. Local institutions are being consolidated by good governance policies, by aid programs that defend indigenous cultures and know-hows and champion the ethno-federation project, and by the democratisation process. Local spaces are now criss-crossed by a network of co-operatives, edir ${ }^{9}$ and community groups, as well as popular tribunals, militias, political bureaus and other political cells. Regardless of the group they belong to, these associations follow very diverse models of organisation that reflect local differences in organisation and political culture, for 
instance between the centre and its peripheries (Markakis, 2014). These groups are either organised according to a top-down chain of command, where the members are not given the opportunity to choose their representatives (and especially not their President or Treasurer, in the case of a cooperative), or according to a more bottom-up model in areas where cash crops are predominant (Cramer et al., 2014). These models reflect a lack of political purpose in these scale shifts, which reinforce local political structures without addressing the confiscation of political power by the upper echelons.

In Ethiopia, the transformations occurring at the opposite ends of the scale are characterised by an "expansion" of the local and by a consolidation of the federal echelon. The current reorganisation of the local scale in Ethiopia is only partially documented, and this issue aims to supplement this gap. This process follows two main paths. The reform of the kebele investigated by R. Emmeneger et al. (2011) involves the development of local institutions, which serve both a governmental function (development of the kebele council) and an administrative one (nomination of kebele managers as part of the administrative decentralisation process). To which extent did this reform transform local spaces, and therefore the local scale itself? Scholarship is still sparse on this question. As a consequence of this institutional promotion (or simply of this increased recognition), local issues have shifted up slightly towards the higher echelons, somewhere between the village and the municipality - while at the same time, the infra-communal level (the sub-kebele) was being developed by administrative reforms. As a consequence, while municipal authorities are increasingly taking control of public affairs (Tegegne Gebre-Egziabher, 2014), the role of the kebele seems confined to political surveillance operations (Di Nunzio, 2014) and locked in a form of "scalar imprisonment" (Planel, 2015).

Meanwhile, the federal echelon where the small ruling elite operates has remained intact, and possibly become stronger. The symptoms of this political grabbing are manifold, especially in land management (Chinigo, 2014). Contrary to Tom Lavers (2012) we do not believe that this fact can be explained by the recentralisation of power, as the powers have never actually been delegated down to the lower echelons and land management has always remained a highly centralised process (Crummey, 2000). Although the Constitution recognises the kellel's (regional State's) competences in terms of land management, the central State's interference with regional affairs leaves decentralised government with a very limited margin of action. While everyday land management involves every echelon of the Ethiopian administration - including the lowest and most local ones, which gain a great deal of authority from their monopolistic management of land tenure - the attribution of concessions remains the privilege of the upper echelons. The Federal Department of Agriculture selects investors, delineates the plots, negotiates and signs the contracts, and raises income that should normally be collected (via taxes) by the regional States (Dessalegn Rahmato, 2011; Labzae, 2014).

The federal government has officially taken over the control of land management through the creation in 2009 of the Federal Land Bank, with an agency within the Department of Agriculture (AISD ${ }^{10}$ ) responsible for its management. The Land Bank is directly funded by the regional States on the basis of their "reserves", which are determined by an inventory carried out by the Federal Department of Agriculture. These inventories, which look at the amount of rural land registered, are inconsistently 
executed depending on the regions. Additionally, land registries are created on a double level (federal and regional), and regional States sometimes ignore the exact extent and allocation of their own "land resources", given that they are mostly responsible for local registration procedures. The procedure for the verification/ validation of land availability by regional States provides a clear picture of this situation: its role is more to legitimate the pre-emption of land operated by the federal State in the regions than to deliver a realistic assessment of land reserves. This shortcircuiting of scale means that the regional level is pre-empted by the federal: federal authorities are not just confiscating the lower echelons' legal powers but also diverting the tax income that they were meant to receive, along with the various privileges attached to this type of transactions.

The relation of power arising from the direct confrontation between on the one hand a small and powerful political elite and on the other hand the redesigned local scales usually plays out to the detriment of the local. This centralisation of power contributes consolidating authoritarianism - all the more that the structuration of the supposedly more democratic local level conceals a reinforcement of constraints. For instance, the lower echelons are affected by strong financial pressure from the upper levels. The kellel do have their say in the management of municipal budgets ${ }^{11}$ and in local planning, but the delivery of urban development plans, although originally allocated to the municipalities by the Constitution, is rarely conducted on a local scale: for lack of sufficient funds, the local authorities hand over the delivery to the kellel-level Urban Agency. In turn, these regional Urban Agencies themselves often hand over the delivery of the plans to consultants from independent agencies. Most of these architecture and urban planning agencies are based in Addis Abeba, and in most do not only operate in the field of consultancy: they also train professionals in the capital's higher education institutions, or hold (or have held) diverse administrative or political responsibilities (Bridonneau, 2014a). This combination of roles facilitates the circulation of these elites across Ethiopia's various scales, all the more easily that these consultancies usually have strong links with the federal scale. The other stakeholders have a more limited ability to contribute to the federal construction and interact with different levels of power.

However, glocalisation does have a real impact as this contact with the global provides local players with new resources. These financial resources, standards and values are feeding into new forms of resistance - some of which have become more passive, and most of which are ineffective (Di Nunzio, 2014). More frequently, these resources are appropriated by new social categories like the urban middle classes, the educated youth, Pentecostal evangelists, rich farmers and new tourism entrepreneurs. In small heritage towns, the development of tourism has facilitated intense glocal contact. A new class of entrepreneurs has harnessed new income streams from tourism, for instance via complex sponsorship strategies (Bridonneau, 2013). These young entrepreneurs often invest locally in the hotel trade, developing ambitious real estate strategies, and building partnerships with foreign investors, with whom they usually have personal links. Most of them have built their capital from land grabbing and real estate development. Their economic power and the limited networks they can draw upon are insufficient for most of them to develop activities outside of the tourist sector. However, due to their relation with the global, these players are discovering and incorporating new standards and values. Although some of them openly build links with the Party in order to contribute to the country's "development" but also to gain 
better access to State resources, these players are also expressing their dissatisfaction with the local authorities' weaknesses. In Lalibela, where entrepreneurs have entered a conflict with the Church administration, they tend to turn to the upper echelons (regional and federal) to get their voices heard and seek mediation. It appears that the upper echelons, often led by admired political personalities, are more frequently seen as an incarnation of the State than local administrations, perceived as weak and incompetent ${ }^{12}$.

The recent analysis of resettlement programmes reaches the same conclusions. Since the first half of the $20^{\text {th }}$ century, displacing and resettling populations has been a key instrument of territorial planning and control (Pankhurst, 1992; Dessalegn Rahmato, 2003; Pankurst, Piguet, 2009). This practice has been transformed by the growing intervention of non-State stakeholders, in both rural and urban areas (Labzaé, 2014; Bridonneau, 2014b). When international donors, bilateral cooperation stakeholders or NGOs are involved in population displacement programmes, they create constraints that curb the State's power - for instance, by tying aid payment to the State meeting certain standards and rules set out in international operational manuals (World Bank, 2001). By complicating relations of power, these programmes can punctually and momentarily disrupt the exercise of power by providing the citizens with a margin for negotiation, or even for protest. However, the donors' interventions are usually channelled through ad hoc administrations created under the authority of the Federal government. Built on purpose for the delivery of the projects to facilitate good governance, these administrations create committees of civil society representatives and organise public consultation meetings to stimulate local democracy. Consequently, although the collusion between the experts from hybrid administrations and the local authorities remains very strong, the latter remain the populations' main point of contact. The decision-making lines are moving to reaffirm the power of the federal echelon, which remains the donors' main interlocutor.

\section{Scale as a "deciphering method"13}

33 These concrete situations reflect the interest of scale as a method through which to understand the changes undergone by Ethiopia, and as a tool through which to decipher political and social transformation. The structuration of scale can help us analyse local case studies as examples of the rearrangement of power and power relations. The contributions compiled in this issue all question the notion of a "glocal Ethiopia" by rooting their analyses in specific local spaces and/or objects that reflect the developmental transition - taking in its background, its suddenness, its regional differentiation and its stakeholders, as well as its political, economic and social dimensions.

This issue gives pride of place to young researchers (five out of seven contributions have been written by researchers whose $\mathrm{PhD}$ theses are either in development or have been defended between 2009 and 2014). The contribution brought by European research projects (Chinigo and Fantini, Nyssen et al.) is all the more essential that most scholarship on contemporary Ethiopia currently comes from international - and in particular, English-speaking - academic circles. In order to meet the demands of a scale-based approach, this issue necessarily cuts across disciplines. Political scientists, historians, geographers and environment scientists are bringing a diverse outlook on 
the changes undergone by Ethiopia: some by focussing on a local (Chiningo and Fantini; Lefort) or a regional approach (Pinauldt); others by analysing scale structuration processes through religious phenomena (Bach), heritage (Josse-Durand; Blanc et Bridonneau) or the environment (Nyssen et al). This issue features articles that are for the most part based on ethnographic fieldwork projects spanning over diverse periods of time, that pay a particular attention to the markers of change in local spaces. All share a concern with developing an in-depth understanding of change and putting it into perspective with earlier, more or less remote periods. Years or even decades of fieldwork have allowed the authors to gain a very precise understanding of the sociopolitical and economical mutations at work in Ethiopia's local spaces, as illustrated by René Lefort's article. This issue also documents a great diversity of regional situations: from Ethiopia's historical centres of power to the Amhara and Tigray highlands in the North (Lefort, Nyssen et al., Blanc and Bridonneau), the Somali border (Pinauldt) or further South, the Omoro region (Chinogo and Fantini) and the Konso territory (JosseDurand).

These different viewpoints and areas of focus depict Ethiopia in the midst of a reorganisation process. Starting from a case study located in the Oromia region, Davide Chinigo and Emanuele Fantini show very clearly how a "Thermidorian situation" can translate into a very original situation in Ethiopia. The authors analyse agrarian modernisation reforms (and in particular the transformation of structures such as cooperatives, micro-credit institutions or small businesses) in the West Arsi area to illustrate the combination of economic liberalisation and State reinforcement in contemporary Ethiopia.

Concerning Ethiopia's northern mountains, Jan Nyssen et al. present a synthetic analysis of the endogenous and exogenous factors of environmental change in Ethiopia, in particular in terms of soil condition. They deliver an assessment of the evolution of soil management and in particular conservation policies, which have increased agricultural production without reducing poverty. Always in the North, but with a much more social reading of scale repositioning, René Lefort presents a critical perspective on the fast development of cash crops. Lefort highlights the social reorganisation associated with this development in a village of the Amhara region. By articulating his presentation of the new cash crops with that of new figures that have emerged in local society, his article illustrates society's fast structuration into social classes and questions the potential political consequences brought along by this process.

In the Somali region, Géraldine Pinauldt shows how the federal echelon has taken control of health and environment standards, placing constraints on exports (towards the Gulf countries) in an attempt to assert its power over export resources such as Somali cattle, which had long escaped its control. The author shows the obstacles encountered by this attempt, and how it resulting in relations of power becoming more complex rather than increasing the federal State's control over this resource. JeanNicolas Bach demonstrates how global and contemporary debates on Islam, and in particular radical Islam, are being instrumentalized by the State in an attempt to keep Ethiopian Muslims in check and control resistance and protest. In doing this, Bach reminds us that religion can act as a powerful scale structuring factor in some societies.

Two articles look at heritage, in the North's traditional natural and cultural heritage sites, and in the South's new "cultural landscape" (Guillaume Blanc and Marie 
Bridonneau, Chloé Josse-Durand). In the northern sites, Guillaume Blanc and Marie Bridonneau remind us how glocal contact has long happened at the detriment of the local, which has been crushed by top-down institutions. On the Konso territory, Chloé Josse-Durand shows how the State has seized an opportunity to redefine global heritage in order to support its stances on ethnic federalism. Both contributions tend to highlight how heritage has been supporting and reinforcing the reorganisation of politics caused by globalisation.

Considered together, the articles in this issue shed a new light on shifts in scale. They highlight the emergence of new political arenas and the renegotiation of local powers. From a social perspective, they show the emergence of new figures - in particular, those of entrepreneurs with a foothold in local and regional spaces (Pinauldt), brokers and consultants (Josse-Durand, Blanc and Bridonneau) or rich farmers (Lefort), revealing an increased stretch and differentiation of social groups. All contributions depict an increasingly structured interface between Ethiopia and the world, generating both money making and social climbing opportunities, and a toughening of the State's authoritarian power (Chinigo and Fantini), counterbalanced in some cases by other anti-centric powers, in particular in the eastern margins (Pinauldt). The regime is however concerned that some groups might be marginalised by the effects of "Glocal Ethiopia" - whether those are new proletarians (Lefort) or antagonistic religious groups (Bach). New players, new values and new references are thus structuring local spaces, all the while contributing to a diversification of the social body which promises to bring about a new wave of equally radical change.

\section{BIBLIOGRAPHIE}

Aalen Lovise, 2011. Revival of tradition? The power of clans and social strata in the Wolayta elections. In Kjetil Tronvoll (dir.), Contested Power: Traditional authorities and multiparty elections in Ethiopia, Leiden, Brill Publishers, p. 111-135.

Abbink J., 2011. Ethnic-based federalism and ethnicity in Ethiopia: reassessing the experiment after 20 years. Journal of Eastern African Studies, 5, ${ }^{\circ} 4$, p. 596-618.

Abbink J., Hagmann T. (dir.), 2013. Reconfiguring Ethiopia: the politics of authoritarian reform. Routledge, $240 \mathrm{p}$.

Achamyeleh Gashu Adam, 2014. Land Tenure in the Changing Peri-Urban Areas of Ethiopia: The Case of Bahir Dar City. International Journal of Urban and Regional Research, n 38, p. 1970-1984.

Admassu Bezabeh, Asayehgn Desta, 2014. Banking Sector Reform in Ethiopia. International Journal of Business and Commerce, Vol. 3, n 8, p. 25-38.

Assefa Fiseha, 2014. Development with or without Freedom? In Dessalegn Rahmato et al., Reflections on Development in Ethiopia. New Trends, Sustainability and Challenges, Forum for Social Studies, Friedrich Ebert Stiftung, Addis-Abeba, p. 67-96 
Aspen, H., 2002. Models of Democracy - Perceptions of Power. Governement and Peasantry in Ethiopia. In Bahru Zewde et Pausewang S., Ethiopia, The Challenge of Democracy from Below, Uppsala, Nordiska Afrikainsitutet, p. 61-70.

Bach J.-N., 2011. Abyotawi democracy: neither revolutionary nor democratic, a critical review of EPRDF's conception of revolutionary democracy in post-1991 Ethiopia. Journal of Eastern African Studies, 5-4, p. 641-663.

Bach J.-N., 2012. "Le roi est mort, vive le roi" : Meles Zenawi règne, mais ne gouverne plus. Politique Africaine, $\mathrm{n}^{\circ}$ 128, p. 143-158.

Bayart J.-F., 2008. Le concept de situation thermidorienne : régimes néo-révolutionnaires et libéralisation économique. Questions de recherches, CERI, Science Po, 24.

Berhanu Adenew, Fayera Abdi, 2005. Research report 3 land registration in Amhara region, Ethiopia. Addis Ababa.

Bjerkli C. L., 2013. Governance on the Ground: A study of Solid Waste Management in Addis Ababa, Ethiopia. International Journal of Urban and Regional Research, 37 (4), p. 1273-1287.

Bosredon P., Bridonneau M., Duroyaume P., 2012. Vers une nouvelle ville éthiopienne ? Essai d'analyse de la fabrique radicale de la ville éthiopienne. Les Annales d'Éthiopie, vol. 27, p. 153-177.

Brenner N., 2004. New States Press, Urban Governance and the Rescaling of Statehood. Oxford, Oxford University Press.

Brenner N., 2001. The limits to scale? Methodological reflections on scalar structuration. Progress in Human Geography, 25 (4), p. 591-614.

Bridonneau M., 2014a. Lalibela, une ville éthiopienne dans la mondialisation. Recompositions d'un espace sacré, patrimonial et touristique. Paris, Karthala.

Bridonneau M., 2014b. Déplacer au nom de la sauvegarde patrimoniale et du développement économique? Analyse multiscalaire du programme de resettlement à Lalibela (Éthiopie). L'Espace Politique, $\mathrm{n}^{\circ} 22$.

Bridonneau M., 2013. Gaining a foothold in the world "for a better life" - Encounters between inhabitants and tourists in Lalibela (Ethiopia), a small World Heritage town.Via@, 2013, $n^{\circ}$ 2013-2.

Broussard N. H. et al., 2014. Ethiopia. In Hino H. et Ranis G. (dir.), Youth and Employment in SubSaharian Africa. Working but poor, Routledge, New York, p. 163-231.

Chacko E., Gebre P., 2012. Leveraging the diaspora for development: lessons from Ethiopia. GeoJournal, vol. 78, p. 495-505.

Chinigo, D., 2014. Decentralisation and Agrarian transformation in Ethiopia: extending the power of the federal state. Critical African Studies, 6-1, p. 40-56.

Cramer C., Johnston D., Oya C., Sender J, 2014. Fairtrade cooperatives in Ethiopia and Uganda: uncensored. Review of African Political Economy, vol. 41, n S1, p. 1115-1127.

Dereje Feyissa, 2011. Aid Negotiation: The Un Easy 'Partnership' Between EPRDF and the Donors. Journal of Eastern African Studies, 5:4, p. 788-811.

Dessalegn Rahmato, 2014. Large-Scale Land Investments Revisited. In Dessalegn Rahmato et al., Reflections on Development in Ethiopia. New Trends, Sustainability and Challenges, Forum for Social Studies, Friedrich Ebert Stiftung, Addis-Abeba p. 219-246. 
Dessalegn Rahmato, Alula Pankhurst, Jan Gerrit van Uffelen, 2013. Food Security, Safety Nets and Social Protection in Ethiopia. Addis-Abeba, Forum for Social Studies.

Dessalegn Rahmato, 2011. Land to Investors: Large-Scale Land Transfers in Ethiopia. FSS Policy Debates Series, $\mathrm{n}^{\circ} 1$, FSS, Addis-Abeba.

Dessalegn Rahmato, 2009. The Peasant and the State, Studies in Agrarian Change in Ethiopia 1950s-2000s. Addis Ababa, Addis Ababa University Press.

Dessalegn Rahmato, 2003. Resettlement in Ethiopia - The Tragedy of Population Relocation in the 1980s. Addis Abeba, Forum for Social Studies.

De Waal A., 2013. The theory and practice of Meles Zenawi. African Affairs, 112 (446), p. 148-155.

Di Nunzio M., 2015. Embracing uncertainty: Young People on the Move in Addis Ababa's Inner City. In Cooper E., Pratten D. (dir.), Ethnographies of Uncertainty in Africa, Palgrave Mac Millan, New York, p. 149- 171.

Di Nunzio M., 2014. Do not cross the red line. The 2010 general elections, dissent and political mobilization in urban Ethiopia. African Affairs, 113 (452), p. 409-430.

Elden S., 2013. Secure the volume: Vertical geopolitics and the depth of power. Political Geography, $\mathrm{n}^{\circ} 34$, p. 35-51

Emmenegger R., 2013. Entre pouvoir et autorité. Propriété urbaine et production de l'Etat à Jijiga, Ethiopie. Politique Africaine, $\mathrm{n}^{\circ} 132$, p. 115-137.

Emmenegger R., Sibilo Keno, Hagmann T., 2012. Decentralization to the household: expansion and limits of State power in rural Oromiya. Journal of Eastern African Studies, 5:4, p. 733-754.

Enten F., 2010. Du bon usage des systèmes d'alerte précoce en régime autoritaire. Le cas de l'Ethiopie. Politique Africaine, Vol. 119, p. 43-62.

Fantini E., 2013. Developmental State, economic transformation and social diversification in Ethiopia. ISPI Analysis, n 163, 7 p. http://www.ispionline.it/sites/default/files/pubblicazioni/ analysis_163_2013.pdf

FDRE (Federal Democratic Republic Of Ethiopia, Ministry Of Finance And Economic Development), 2010. Growth and Transformation Plan (GTP) - 2010/11 - 2014/15, Addis Ababa.

Ferguson, J., 1994. The Anti-Politics Machine. “Development”, Depoliticization, and Bureaucratic Power in Lesotho. Minneapolis, University of Minnesota Press, 1994.

Fernandez B., 2011. Household Help? Ethiopian Women Domestic Workers' Labor Migration to the Gulf Countries. Asian and Pacific Migration Journal, 20, p. 433-457.

Foucault M., 2004. Naissance de la biopolitique. Gallimard, Paris, 355 p.

Gascon A., 2008. Shining Ethiopia : l'Éthiopie post-communiste du nouveau millénaire. Autrepart, 48 , p. $141-152$.

Hagmann, T., Abbink, J., 2011, Twenty years of revolutionary democratic Ethiopia, 1991 to 2011. Journal of Eastern African Studies, 5, nº 4, p. 579-595.

Harvey D., 2006. Spaces of Global Capitalism: Towards a Theory of Uneven Geographical Development. Londres, Verso Libri.

Haustein J., Fantini E., 2013. Introduction: The Ethiopian Pentecostal Movement in EthiopiaHistory, Identity and Current Socio-Political Dynamics. PentecoStudies, vol. 12, n ², p. 150-161.

Herod A., M. W. Wright, 2002. Geographies of power. Placing scale. Oxford, Blackwell Publishers. 
Jessop B., 2002. Liberalism, Neoliberalism, and Urban Governance: A State Theoretical Perspective. In Brenner N., Theodore N. (dir.), Spaces of Neoliberalism: Urban Restructuring in North America and Western Europe, London, Blackwell, p. 105-125.

Jonas A., 1994. The scale politics of spatiality. Environment and Planning D: Society and Space, 12 (3), p. 257-266.

Kassahun A., 2012. The effect of Business Process Reengineering (BPR) on public sector organisation performance in a developing economy context. $\mathrm{PhD}$, Business Information Technology and Logistics, RMIT University.

Labzaé M., à paraitre. Les travailleurs du gouvernement. Encadrement partisan et formes du travail administratif dans l'administration éthiopienne. Genèses.

Labzaé M., 2014. Le grand remaniement. Formalisation des droits fonciers et déplacement contraint des populations dans l'Ouest éthiopien. Les cahiers du pôle foncier, $\mathrm{n}^{\circ} 8,30 \mathrm{p}$.

Lefort R., 2013. The theory and practice to Meles Zenawi: A response to Alex De Waal. African Affairs, 112 (448), p. 460-470.

Lefort R., 2012. Free market economy, 'Developmental State' and party-state hegemony in Ethiopia: the case of 'model farmers'. Journal of Modern African Studies, 50, 4, p. 681-706.

Lefort R., 2011. The Ethiopian land-grab: feudalism, leninism, neo-liberalism...plus ça change. Open Democracy, 31/12/2011, http://opendemocracy.net

Lefort, R., 2010. Powers-mengist and peasants in rural Ethiopia: the post-2005 interlude. Journal of Modern African Studies, 48, n 3, p. 435-460.

Markakis J., 2011. Ethiopia. The last two frontiers. James Currey, Woodbridge - Suffolk, Rochester New York, 383 p.

Meles Zenawi, 2012. State and markets: neoliberal limitations and the case for a developmental state. In Akbar Noman, Kwesi Botchwey, Howard Stein, Joseph Stiglitz (dir.), Good Growth and Governance in Africa: Rethinking development strategies, Oxford, Oxford University Press.

Meheret Ayenew, 2014. The Growth and Transformation Plan: Opportunities, Challenges and Lessons. In Dessalegn Rahmato et al., Reflections on Development in Ethiopia. New Trends, Sustainability and Challenges, Forum for Social Studies, Friedrich Ebert Stiftung, Addis-Abeba, p. 3-30.

Nallet C., 2012. Trajectoires d'émergence : « classes moyennes » d'Addis-Abeba entre prospérité et précarité. Annales d'Éthiopie, 2012, n²7, p. 207-225.

Osmond T., 2014. Competing Muslim Legacies along city/countryside dichotomies: another political history of Harar town and its Oromo rural neighbours in Eeastern Ethiopia. Journal of Modern African Studies, 52-1, p. 1-23.

Pankhurst A., 1992. Resettlement and Famine in Ethiopia: the Villagers' Experience. Manchester, Manchester University Press.

Pankhurst A., Piguet F. (dir.), 2009. Moving People in Ethiopia - Development, Displacement \& The State. Woodbridge - Suffolk, Rochester - New York, James Currey.

Pausewang S., 2002a. No environmental Protection without Local Democracy? Why Peasants Distrust Their Agricultural Adviserst. In Pausewang S., Tronvoll K. and Aalen L., Ethiopia since the Derg: A decade of Democratic Pretension and Performance, Londres, Zed Book, p. 87-102. 
Pausewang S., 2002b. A Population Resisting Local Control and Intimidation? The elections in Gedeo, Southern Region. In Pausewang S., Tronvoll K., Aalen L. (dir), Ethiopia since the Derg. A decade of Democratic Pretension and Performance, Londres, Zed Books.

Pedrazzini Y., Vincent-Geslin S., Thorer A., 2014. Violence of Urbanization, Poor Neighbourhoods and Large-Scale Projects: Lessons from Addis Ababa, Ethiopia. Built Environment, vol. 40, $\mathrm{n}^{\circ} 3$, p. 394-407.

Planel S., 2015. Jeux d'échelles et rapports de domination en Ethiopie. In Clerval A., Fleury A., Rebotier J., Weber S., Espace et rapports de domination, Presses Universitaires de Rennes, p. 99-109.

Planel S., 2014. A view of a bureaucratic Developmental State. Local governance and agricultural extension in Ethiopia. Journal of Eastern African Studies, vol. 8, 3, p. 420-437.

Planel S., Jaglin S., 2014. Échelles : partage des pouvoirs et partage de l'espace. In GervaisLambony P., Benit-Gbaffou C., Musset A., Piermay J.L., Planel S. (dir.), La Justice Spatiale et la ville, regards du sud, Karthala, p. 27- 39.

Planel S., 2007. Du centralisme à l'ethno-fédéralisme. La décentralisation conservatrice de l'Ethiopie. Afrique Contemporaine, « Décentralisations et développements », 221, p. 87-105.

Poluha, E., 2002. 'Learning political behaviour: peasant-state relations in Ethiopia'. In Poluha, E., Rosendahl, M. (eds), Contesting 'Good' Governance: Cross-cultural perspectives on representation, accountability and public space, London, Routledge Curzon, p. 101- 136.

Segers K., Dessein J., Nyssen J., Mitiku Haile, Deckers J., 2008. Developpers and farmers intertwining interventions: the case of rainwater harvesting and food-for work in Degua Temben, Tigray, Ethiopia. International Journal of Agricultural Sustainability, 6, n ³, p. 173-182.

Siyoum A.D., Hilhorst D., Pankhurst, A., 2012. The differential impact of microcredit on rural livelihoods: case study from Ethiopia. Journal of Development and Sustainability, vol. 1, $\mathrm{n}^{\circ} 3$, p. 957-975.

Swyngedouw E., 2004, Globalisation or 'glocalisation'? Networks, territories and rescaling”, Cambridge Review of International Affairs, 17, p. 25-48.

Swyngedouw E., 2000. Authoritarian governance, power and the politics of rescaling. Environment and Planning D: Society and Space, 18, p. 63-76.

Swyngedouw E., 1997. Excluding the other: The production of scale and scaled politics. In R. Lee and J. Wills (dir.), Geographies of Economies, London, Arnold, p. 167-176.

Teferi Abate Adem, 2012. The Local Politics of Ethiopia's Green Revolution in South Wollo. African Studies Review, 55, n 3, p. 81-102.

Teferi Abate Adem, 2004. Decentralised There, Centralised Here': Local Governance and Paradoxes of Household Autonomy and Control in North-East Ethiopia, 1991-2001. Africa: Journal of the International African Institute, vol. $74, \mathrm{n}^{\circ} 4$, p. 611-632.

Tegegne Gebre-Egziabher, 2014. Decentralisation and regional and Local Development: Trends and Policy Implications. In Dessalegn Rahmato et al., Reflections on Development in Ethiopia. New Trends, Sustainability and Challenges, Forum for Social Studies, Friedrich Ebert Stiftung, AddisAbeba, p. 133-167.

Tronvoll K., Vaughan S., 2003. The Culture of Power in Contemporary Ethiopian Political Life. Stockholm, Sida (Swedish International Development Cooperation Agency), Sida Studies $n^{\circ} 10$.

Turton D. (dir.), 2006. Ethnic Federalism - The Ethiopian Experience in Comparative Perspective. Oxford, Athens, Addis Ababa, James Currey, Ohio University Press, Addis Ababa University Press. 
UNDP, 2014. Ethiopia, Country Economic Brief.

Uraguchi Zenebe B., 2011. Rural Income Transfer Programs and Rural Household Food Security in Ethiopia. Journal of Asian and African Studies, 47(1), p. 33-51.

Vaughan S., 2011. Revolutionary democratic state-building: party, state and people in the EPRDF's Ethiopia. Journal of Eastern African Studies 5, n 4, p. 619-640.

Vaughan S., 2003. Ethnicity and Power in Ethiopia. Thesis for the degree philosophiae doctor, Edinburgh, University of Edinburgh.

Vaughan S., Gebremichael M., 2011. Rethinking Business and Politics in Ethiopia: The role of EFFORT, the Endowment Fund for the Rehabilitation of Tigray. Africa Power and Politics, Research $n^{\circ} 2$.

World Bank, 2001. Operational Policy 4.12. - Involuntary Resettlement. Washington.

World Bank, 2013. Ethiopia Economic Update: Laying the Foundation for Achieving Middle Income Status. http://www.worldbank.org/en/country/ethiopia/publication/ethiopia-economic-update-layingthe-foundation-for-achieving-middle-income-status

Yukichi Mano, Takashi Yamano, Aya Suzuki, Tomoya Matsumoto, 2011. Local and Personal networks in Employment and the Development of Labor Markets: Evidence from the Cut Flower Industry in Ethiopia. World Development, vol. 39, $\mathrm{n}^{\circ}$ 10, p. 1760-1770.

\section{NOTES}

1. For instance, roads, hydro-electric dams but also large-scale sugar industry.

2. SDPRP (Sustainable Development and Poverty Reduction Program), finalised in 2002; PASDEP (Plan for Accelerated and Sustainable Development to End Poverty), 2005/2006-2010/2011.

3. ADLI programme (Agricultural-Development Led Industrialisation).

4. Laquelle devrait être palliée par l'exportation de biens industriels mais plus certainement par les productions agricoles cultivées sur les terres du land grab.

5. A lower echelon of the Ethiopian administration, the wereda is the equivalent of a district and the kebele that of a town.

6. See Rony Emmenegger's analyses on the « reformed kebele ».

7. See Planel, Jaglin, 2014; Herod, Wright, 2002.

8. To quote Michel Foucault's extremely relevant terms (2004).

9. A mutual help association designed to mutualise the cost of social events and ceremonies.

10. Agricultural Investment Support Directorate.

11. Field observations, Planel S., Wolayta, February 2015.

12. Field observations, Bridonneau M., Lalibela, août 2014.

13. Foucault $(2004$, p. 192). The expression in this text doesn't strictly refer to scale, but Foucault's analysis of micro-power does illustrate perfectly this issue's usage of scale structuration. 


\section{AUTEURS}

SABINE PLANEL

Sabine Planel, sabine.planel@ird.fr, est Chargée de recherche IRD et membre de l'UMR Prodig.

\section{MARIE BRIDONNEAU}

Marie Bridonneau, bridonneaumarie@gmail.com, est Maitre de conférences à l'Université Paris Ouest Nanterre La Défense et membre de l'UMR Lavue-Mosaïques. 